\title{
PENGGUNAAN KATA EMOSI YANG MENGGAMBARKAN PENGALAMAN AFEKSI DALAM BAKUSEDU
}

\author{
Darsita Suparno \\ darsitasuparno@uinjkt.ac.id \\ Fakultas Adab dan Humaniora \\ Universitas Islam Negeri Syarif Hidayatullah Jakarta
}

\begin{abstract}
Abstrak
Tujuan penelitian ini adalah untuk mengkaji penggunaan kata emosi yang menggambarkan pengalaman dalam "bakusedu". Masalah penelitian difokuskan pada penggunaan kata emosi dan makna yang menggambarkan pengalaman afeksi yang dituturkan dalam bahasa Manado. Adapun sub masalah yang akan dibahas dalam penelitian ini, adalah: menemukan proposisi yang terkait dengan pengungkapan emosi informan melalui hubungan proposisi dalam monolog, dan dialog bakusedu, menemukan penggunaan kata emosi yang diungkapkan melalui setiap pernyataan dalam bakusedu itu yang dapat menggambarkan pengalaman afeksi informan? dan menemukan taksonomi kosa kata emosi dalam Bakusedu itu?. Penelitian ini berbasis kolaborasi antara linguistik dan sosiologi. Secara metodologis, penelitian ini merupakan penelitian bersifat alamiah karena sumber datanya diamati secara langsung. Peneliti bertindak sebagai human instrument. Data emosi bersumber pada monolog dan dialog para pelaku dalam bakusedu. Temuan kosakata emosi dan fungsinya di dalam masyarakat yaitu kosa kata dan frase yang mencakup karakter manusia seperti bekerja sebagai ibadah, musyawarah untuk dapat menyelesaikan masalah, kosa kata emosi positif, netral dan negatif.
\end{abstract}

Kata Kunci: Kata emosi, Karakter fisik, Bahasa sehari-hari

\begin{abstract}
The objective of the research is to find out the usage of emotion word that represented "bakusedu". The Bakusedu is vernacular language literature, such as short story is one of reality construction of Manado's culture, in the form of oral and writing represented in symbols. For Manado's people bakusedu is a kind of their societies' advice which cannot be forgot and separated from their live; it also serves a means of social communication in order to teach, educate, to draw characters, emotion, and inform values for younger generation. This research's problem is focused on the study of forms of emotion's word and meaning in bakusedu which is spoken in Manado language. This
\end{abstract}


research can be classified as a case study using eclectic approach which combines theories of linguistic and sociology of literature. Methodologically, in this research is natural in characteristics because the primary data are observed directly. The form of culture value in this bakusedu identified in writing. The researcher serves as human instrument. The data emotion words and phrases are gathered from monolog and dialog content of its bakusedu that is spoken by Manado ethnic group in North Sulawesi. The finding of emotion words and it function in the society are found, namely words and phrases which cover human character such as: working as mercy of god, discussion to solve problem, physical character; several kind of emotion words, such as positif, netral and negative

Keywords: Emotion words, physical character, vernacular language

\section{A. Pendahuluan}

Jika mengacu pada pengertian bahwa kebudayaan adalah hasil cipta manusia, maka Bakusedu dapat diposisikan sebagai salah satu bukti, bahwa masyarakat Sulawesi Utara memiliki kualitas produksi budaya yang luar biasa. Selain, bakusedu masyarakat itu masih memiliki produksi budaya lainnya, seperti: tinutuan, mapalus, sitou tumou tou, ikang fufu, rumah adat Minahasa, batik bentenan, tarian ma'engket, tradisi sastra lisan dan lain sebagainya.

Kebudayaan atau budaya menurut Koentjaraningrat (1996) adalah keseluruhan sistem gagasan, tindakan dan hasil karya manusia dalam rangka kehidupan masyarakat yang dijadikan milik diri manusia dengan belajar. ${ }^{1}$ Penjelasan tersebut merujuk pada gagasan yang dipaparkan oleh J.J. Honigmann (1973) tentang wujud kebudayaan atau disebut juga gejala kebudayaan, Honigmann mengklasifikasi kebudayaan ke dalam tiga wujud, yakni: 1) kebudayaan dalam wujud ide, 2) pola tindakan, dan 3) artefak atau benda-benda. ${ }^{2}$

Mengacu kepada konsep di atas, jika dikembalikan pada realita yang ada di kehidupan masyarakat Sulawesi Utara kiranya dapat dipahami bahwa setiap wujud kebudayaan yang ada dalam masyarakat itu dapat diamati secara cermat. Sejalan dengan itu, pertanyaan dasar yang dapat diajukan "Apakah ada yang namanya budaya Bakusedu? Ada beberapa budaya besar yang terkait dan selalu dikaitkan dengan kebudayaan Sulawesi Utara dalam pencariannya, yakni istilah budaya lokal, budaya timur, dan pengaruh Kristen sebagai agama mayoritas. Pengaitan itu pada dasarnya bukan mengarah kepada pencarian jawaban atas apa yang dimaksud kebudayaan di Sulawesi, tetapi lebih cenderung menjadi sesuatu yang dipaksakan sebagai turunan dari kepentingan ideologis. Penelitian ini membahas salah satu unsur kebudayaan yakni bahasa, khususnya penggunaan kata emosi yang menggambarkan pengalaman afeksi dalam bakusedu.

\footnotetext{
${ }^{1}$ Koentjaraningrat. Pengantar Ilmu Antropologi. (Jakarta: Rineka Cipta, 1996)., hal 6

${ }^{2}$ J.J. Honigmann. 1976. Sebagaimana dikutip oleh Koentjaraningrat (1996)., hal 6
} 
Bakusedu adalah narasi yang bersifat humor berisi pertuturan (speech act), untuk menginformasikan sesuatu, dan sering juga dapat mempengaruhi mitra bicara atau pembaca. Contoh data :

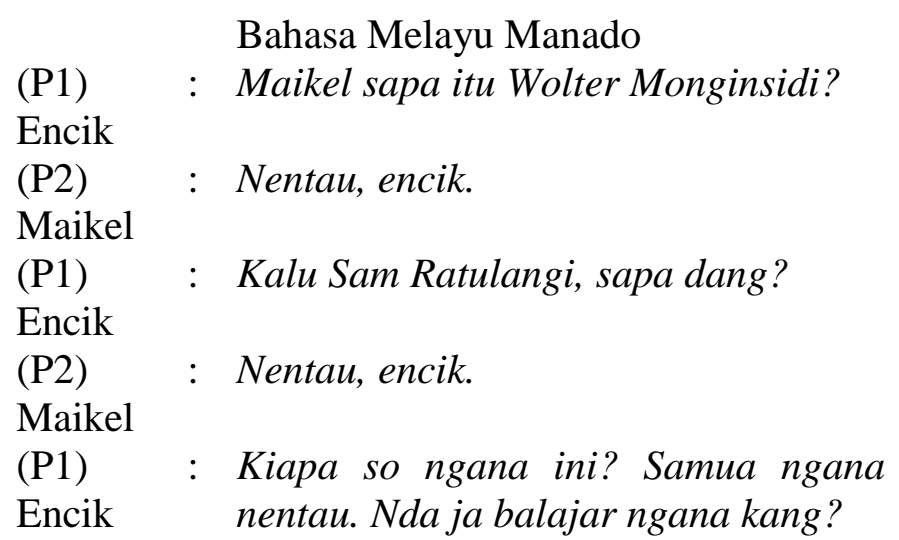

\author{
Bahasa Indonesia \\ 'Maikel siapa itu Wolter \\ Monginsidi? \\ 'Tidak tahu, bu guru.
}
'Kalau Sam Ratulangi, siapa?
'Tidak tahu, bu guru.

'Mengapa kamu begitu? Semua kamu tidak tahu, berati tidak pernah belajar'

Keterangan: $\mathrm{P} 1=$ Pembicara $; \mathrm{P} 2=$ mitra bicara

Ditinjau dari bentuk bahasa yang digunakan dalam narasinya, bakusedu diciptakan dengan tujuan: a) menghibur pembaca; b) kritik sosial terhadap segala bentuk ketidakharmonisan situasi yang terjadi di tengah masyarakat. Atas dasar bentuk bahasa itu, bakusedu dianggap sebagai keseluruhan pemikiran yang dibuat atau diciptakan oleh masyarakat Sulawesi Utara, khususnya Manado. Bakusedu ditinjau dari bentuk bahasa yang digunakannya dapat menggambarkan adanya keadaan emosional yang mengindikasikan pengalaman-pengalaman, sistem ide, pola pikir, perbuatan yang menggambarkan suatu keadaan kelompok manusia. Fakta itu dapat dikaitkan dengan, pendapat Ruth Benedict (1934) yang melihat kebudayaan sebagai pola pikir dan perbuatan yang terlihat dalam kehidupan sekelompok manusia yang membedakannya dengan kelompok lain.

Dalam kajian linguistik, emosi diasumsikan dapat diungkapan melalui berbagai proposisi-proposisi yang dibentuk oleh penutur bahasa yang bersangkutan. Proposisi atau pernyataan itu dibentuk melalui cerita, entah berbentuk monolog, dialog, atau narasi. Pernyataan-pernyataan itu dapat menunjukkan pemaknaan individu atau kelompok sosial mengenai pengalaman hidupnya. Menurut Larson (1984) proposisi adalah objek semantis yang berkaitan dengan teks. Dalam penelitian ini, proposisi dianggap sebagai bentuk bahasa yang digunakan oleh penutur bahasa untuk menyampaikan ide-ide atau berbagai pokok bahasan. Proposisi-proposisi yang diujarkan oleh penutur bahasa dianggap memiliki kandungan berbagai pernyataan termasuk situasi emosi yang menggambarkan berbagai pengalaman, termasuk pengalaman afeksi.

Dipilihnya kosa kata emosi yang menggambarkan pengalaman afeksi dalam monolog, dialog dan narasi bakusedu sebagai objek penelitian, didasarkan pada 
beberapa faktor, yaitu: 1) ada gambaran suatu kisah; 2) menyampaikan berbagai realitas yang ada yang melingkupi kehidupan penutur bahasa.

Dengan memperhatikan dan mencermati latar belakang masalah yang disampaikan di bagian depan itu secara panjang lebar, dan dengan memperhitungkan kendala-kendala pemulisan yang pasti muncul di dalam pelaksanaan penelitian ini, juga dengan mengkalkulasi jangkauan-jangkauan penulisan ihwal emosi yang selama ini telah dilakukan, maka masalah-masalah untuk penelitian terhadap entitas emosi dalam bahasa Manado ini dapat dirumuskan seperti berikut:

1. Bagaimana proposisi yang terkait dengan pengungkapan emosi informan melalui hubungan antarproposisi dalam monolog, dan dialog bakusedu?

2. Bagaimana penggunaan kata emosi yang diungkapkan melalui setiap pernyataan dalam bakusedu itu dapat menggambarkan pengalaman afeksi informan?

3. Bagaimana taksonomi kosa kata emosi dalam Bakusedu itu?

Manfaat yang diharapkan dapat diambil dari penelitian ini ada dua yaitu manfaat secara teoretis dan praktis.

1. Secara teoretis penelitian ini diharapkan akan memberikan pemahaman baru dalam ilmu linguistik khususnys di bidang leksikologi tentang kajian makna emosi dan pikiran (emotion and states of mind) yang sampai saat ini masing sangat sedikit dikembangkan, sejauh penelusuran penulis dalam kajian kepustakaan dalam konteks penelitian ini.

2. Secara praktis, penelitian ini nantinya dapat dijadikan sebagai acuan bagi para pemerhati bahasa-bahasa daerah dan masyarakat di Sulawesi khususnya Sulawesi Utara untuk dapat terus mempertahankan bahasa Manado dan nilai-nilai budaya dari kepunahan.

\section{B. Analisis Data}

\section{Analisis Hubungan Antarproposisi}

Emosi dalam penelitian ini dipandang sebagai peran yang sangat menonjol dalam kehidupan manusia. Emosi terbentuk melalui perkembangan yang dipengaruhi pengalaman. Secara sosial emosi diatur dengan cara mencari akses ke hubungan interpersonal dan sumber dukungan bersifat nyata. Sedangkan, secara tingkah laku emosi diregulasikan melalui berbagai respon tingkah laku seperti: berteriak, menjerit, menangis, atau menarik diri adalah contoh dari tingkah laku yang tampak untuk mengatur emosi yang bangkit sebagai respon terhadap rangsangan yang diberikan. Emosi juga berguna untuk mengatur proses kognitif yang tidak disadari, seperti process selective attention, memory distortion, penolakan, atau proyeksi atau proses kognitif yang disadar, seperti menyalahkan diri sendiri atau menyalahkan orang lain. ${ }^{3}$

${ }^{3}$ Frijda, N.H. The Emotion. (Cambridge: Cambridge University Press)., 164 
Keadaan ini didorong oleh reaksi sosial diakui atau tidak diakui atau tindakan norma sosial melalui rasa sopan dan perasaan malu dan bersalah yang ada dalam kelompok sosial. Emosi secara kognisi berhubungan dengan kehidupan manusia dan membantu individu mengelola, mengatur emosi atau perasaan dan mengendalikan emosi agar tidak berlebihan.

Mengacu kepada pengklasifikasikan emosi yang diajukan Gray (2004), emosi dalam penelitian ini meliputi keadaan emosi positif, emosi netral, dan emosi negatif. Pada penelitian ini, konsep emosi digunakan sebagai acuan dalam menemukan penggunaan kalimat-kalimat yang diasumsikan mengandung kata dengan konsep emosi dalam dialog bakusedu Manado. Selain konsep emosi, penemuan proposisi juga didasarkan pada sudut pandang dalam dialog, yaitu penutur dan mitra tutur dalam bakusedu adalah pelaku dalam wacana bakusedu itu. Penutur adalah pelaku yang terlibat langsung pada kejadian dalam monolog, dialog, narasi bakusedu, mitra tutur adalah orang yang memberikan respon dean tanggapan atas kejadian dalam dialog. Melalui kedua acuan tersebut di atas dan proses pengolahan data untuk mendapat penggunaan kata emosi yang menggambarkan pengalaman afeksi.

Dalam bab ini, peneliti menganalisis teks bakusedu dalam bentuk dialog maupun monolog yang mengungkapkan keadaan emosi. Tiap-tiap topik tentang emosi akan dipaprakan melalui analisis gugus proposisi dalam teks bakusedu.

Gugus proposisi yang mengandung situasi emosi di analisis menggunakan hubungan antarproposisi untuk menemukan dan memahami proposisi yang mengungkapkan penggunaan kata emosi yang menggambarkian pengalaman afeksi itu. Selanjutnya, temuan proposisi diidentifikasi terkait dengan aspek emosi yang diungkapkan dalam komponen makna dari inti proposisi. Temuan-temuan aspek emosi pada tahap berikutnya, diklasifikasikan dengan mengacu kepada konsep emosi dan jenis-jenis emosi untuk mengetahui kosa kata emosi apa yang digunakan dalam setiap interaksi ujaran. Berdasarkan penjelasan di atas, analisis dalam penelitian ini disajikan sebagai berikut.

\section{Analisis Proposisi Terkait dengan Ungkapan Emosi}

Pemahaman tentang penggunaan kata emosi yang diungkapkan dalam bahasa daerah dalam hal ini bahasa Melayu Manado (selanjutnya disingkat BMM) yang deiungkapkan dalam narasi berbentuk dialog ataupun monolog bakusedu tidak dapat ditemukan dan diphami langsung dalam narasi atau proposisi-proposisi pembentuknya. Hal ini terjadi karena keadaan emosi sering secara tidak langsung disampaikan dalam narasi tetapi melalui jalinan cerita, yaitu melalui hubungan yang ada antarproposisi.

Melalui jalinan cerita akan dapat ditemukan proposisi-proposisi yang mengungkapkan komponen makna emosi penutur. Proposisi tersebut selanjutnya akan ditarik dalam analisis penggunaan kata emosi guna menemukan pengalaman afeksi yang ada. Berdasarkan uraian di atas, analisis pada subbagian ini akan diklasifikasikan berdasarkan 18 topik emosi negatif, 2 emosi netral, dan 13 topik emosi positif yang ditemukan dalam gugus proposisi, pengklasifikasian itu dapat dilihat dalam tabel berikut: 


\section{Tabel 1 Taksonomi Kata Emosi}

\begin{tabular}{|c|c|c|c|c|c|c|c|c|}
\hline \multirow[b]{2}{*}{1} & \multicolumn{3}{|c|}{ Emosi negatif } & \multirow{2}{*}{$\begin{array}{l}\text { Emosi } \\
\text { netral } \\
\text { rasa } \\
\text { bosan }\end{array}$} & \multicolumn{4}{|c|}{ Emosi positif } \\
\hline & Kemarahan & $\begin{array}{l}1 \\
1\end{array}$ & Ketakutan & & 1 & Minat & $\begin{array}{l}1 \\
1\end{array}$ & kepuasan \\
\hline 2 & Kesedihan & $\begin{array}{l}1 \\
2\end{array}$ & Rasa ngeri & $\begin{array}{l}\text { rasa } \\
\text { heran }\end{array}$ & 2 & Semangat & $\begin{array}{l}1 \\
2\end{array}$ & keinginan \\
\hline 3 & Kesalahan & $\begin{array}{l}1 \\
3\end{array}$ & Tidak suka & - & 3 & Gembira & & - \\
\hline 4 & Bersalah & $\begin{array}{l}1 \\
4\end{array}$ & Hina & - & 4 & $\begin{array}{l}\text { Agak } \\
\text { gembira }\end{array}$ & & - \\
\hline 5 & Putus asa & $\begin{array}{l}1 \\
5\end{array}$ & Rasa benci & - & 5 & Suka & & - \\
\hline 6 & $\begin{array}{l}\text { Perasaan } \\
\text { malu }\end{array}$ & $\begin{array}{l}1 \\
6\end{array}$ & Bemusuhan & - & 6 & Cinta & & - \\
\hline 7 & Rasa malu & $\begin{array}{l}1 \\
7\end{array}$ & $\begin{array}{l}\text { Marah- } \\
\text { marah }\end{array}$ & - & 7 & Kegemaran & & - \\
\hline 8 & Benci & & & - & 8 & Kesenangan & & - \\
\hline 9 & Jijik & & - & - & 9 & Kebahagiaan & & - \\
\hline 10 & Malu-malu & & - & - & 10 & Hasrat berahi & & - \\
\hline
\end{tabular}

Sumber: Gray Peter. 2002. Phsychology. (New York: Worth Publishers, 2002)., p 220

\section{Hubungan Keadaan-Hasil}

Untuk menemukan proposisi yang mengandung ungkapan yang bersifat emosional digunakan proposisi yang menunjukkan keadaan-hasil, penulisan mengikuti saran Larson (1984) dengan memberi simbol: keadaan-HASIL. Untuk mengetahui proposisi keadaan-HASIL dapat dilihat pada data nomor 1 dengan topik kemarahan, sebagai berikut:

\section{Topik: Pi ka lao 'Pergi ke laut'}

Dalam gugus proposisi berikut ini diidentifikasi terdapat ungkapan beripa pernyataan yang mengandung keadaan emosi, seorang penutur bahasa. Kemarahan dijelaskan sebagai keadaan sangat tidak senang karena diperlakukan kurang baik, gusar atau berang. Terkait dengan emosi ini, peneliti menemukan gugus proposisi pada data nomor 1 sebagai berikut:

Bahasa Melayu Manado

P1 : Co ngana pi ka lao sana kong batobo cari akang papa pe prao tu
Bahasa Indonesia

'Coba kamu pergi ke laut, lalu bernenang cari perahu ayah yang 
da talapas tadi sore!

P2 : Muka brot dengan mata basar. Ngana pe soe deng ngana, ngana kira kita robot? tu aer rupa aer eis.., blum lei tu ikang gorango, deng tu tandipang kurang mo cicaro pa kita kalu kita pi batobo skarang.. ja pake ontak sadiki kwak kalu basuru ee! terlepas di laut tadi sore!'

'Muka marah dan mata melotot. Kamu orang sial, kamu kira saya robot? Air laut itu sekarang dingin seperti es, tambahan pula ikan buas seperti gorango, tandipang yang banyak itu akan menyerang dan membunuh saya kalau saya berenang di laut saat ini. Pakailah otak kalau mau memerintah orang lain.'

Selanjutnya guna menemukan keberadaan proposisi yang mengungkapkan penggunaan kata emosi dalam Bahasa Melayu Manado (selanjutnya disingkat BMM) ditelusuri melalui komponen makna inti proposisinya, gugus proposisi tersebut dijelaskan kembali dalam bagan hubungan antarproposisi sebagai berikut:

Skema 1 Hubungan Antarproposisi dalam gugus proposisi 1

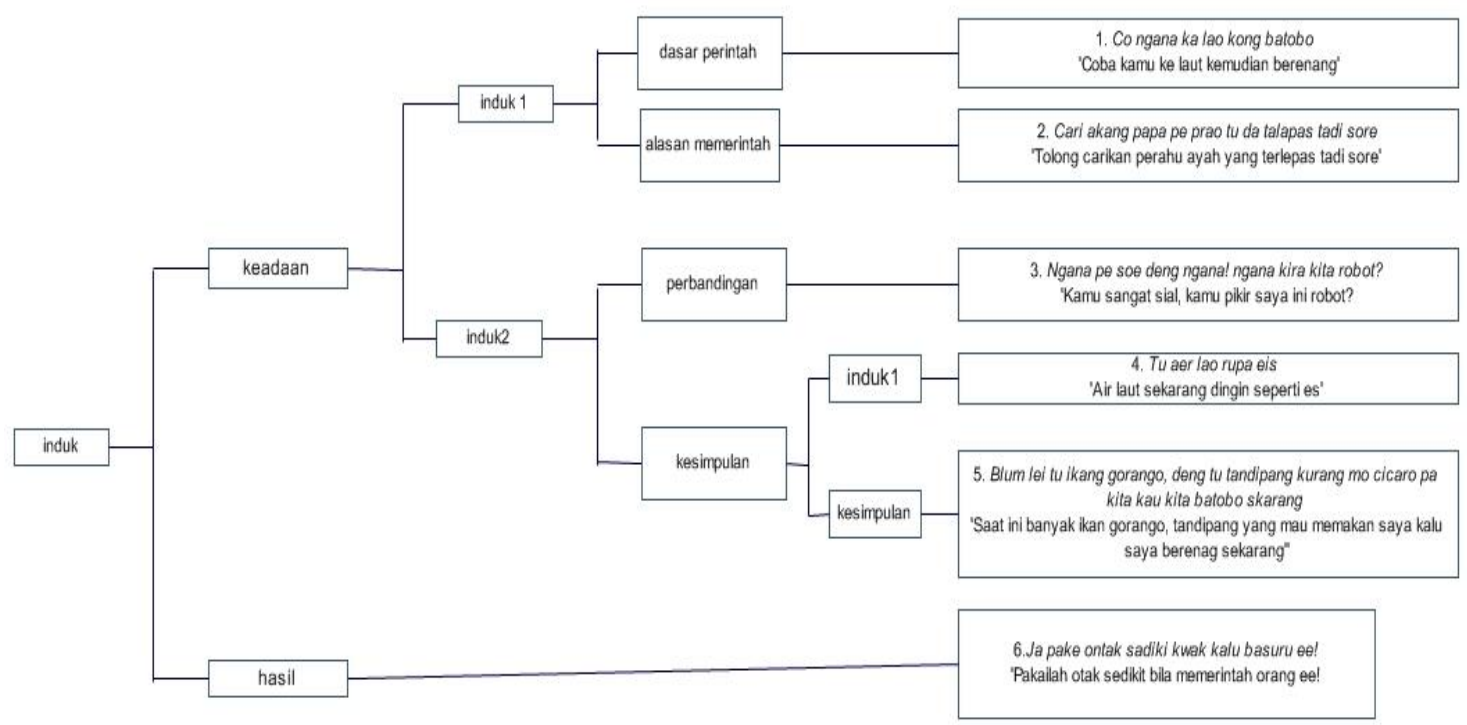

Gugus proposisi 1 pada bagan 1 dibentuk oleh hubungan KEADAAN-HASIL untuk menjelaskan dasar munculnya penggunaan kata emosi yang dikatakan anak kepada ayahnya. Keadaan memiliki dua induk, yaitu INDUK 1 dan INDUK 2. Proposisi INDUK 1 memiliki hubungan yang dibentuk oleh hubungan dasar PERINTAH-ALASAN memerintah yang menjelaskan tentang Sang ayah memerintahkan kepada anaknya untuk berenang ke laut. Proposisi alasan muncul dari suatu keadaan yaitu perahu sang ayah terlepas di laut pada waktu sore hari. Proposisi INDUK 2 memiliki hubungan perbandingan-KESIMPULAN. Proposisi perbandingan 
berisi tentang tanggapan anaknya atas perintah sang ayah untuk mencari perahunya pada malam hari di laut.

Kejadian dalam proposisi di atas merupakan proposisi PERBANDINGAN, yaitu sikap ayah yang membandingkan anaknya sama dengan robot. Kejadian dalam proposisi KESIMPULAN terdapat dua induk peristiwa, yaitu INDUK 1 dan INDUK 2. Pada INDUK 1 sang anak menyimpulkan bahwa pada saat itu, air laut dalam keadaan sangat dingin seperti es, dan INDUK 2 sang anak menyimpulkan bahwa saat itu banyak ikan buas, seperti ikan gorango dan ikan berduri yaitu ikan tandipang yang sedang mencari mangsa untuk dimakannya.

Proposisi HASIL dibentuk dari hubungan keadaan-HASIL dalam hubungan tersebut sang anak memberi respon secara emosional atas perintahnya ayahnya dengan mengucapkan kalimat emosi sebagai berikut: ja pake ontak sadiki kwak kalu basuru ee!. Jadi proposisi 1 dapat diidentifikasi mengandung pengungkapan kosa kata emosi. Ungkapan itu berbentuk kalimat perintah, yang dalam kalimat itu terdapat kosa kata ontak 'otak, pikiran, logika'; sadiki 'sedikit'. Kosa kata ontak sering dipakai untuk mengungkapkan keadaan emosi. Ontak diidentifikasi sebagai kosa kata bagian dari tubuh manusia, khususnya bagian kepala yang sering dirujuk dalam kaitannya dengan emosi.

Gugus proposisi 1 pada bagan 1 dibentuk oleh hubungan KEADAAN-HASIL untuk menjelaskan dasar munculnya penggunaan kata emosi yang dikatakan anak kepada ayahnya. Keadaan memiliki dua induk, yaitu INDUK 1 dan INDUK 2. Proposisi INDUK 1 memiliki hubungan yang dibentuk oleh hubungan dasar PERINTAH-ALASAN memerintah yang menjelaskan tentang Sang ayah memerintahkan kepada anaknya untuk berenang ke laut. Proposisi alasan muncul dari suatu keadaan yaitu perahu sang ayah terlepas di laut pada waktu sore hari. Proposisi INDUK 2 memiliki hubungan perbandingan-KESIMPULAN. Proposisi perbandingan berisi tentang tanggapan anaknya atas perintah sang ayah untuk mencari perahunya pada malam hari di laut.

Kejadian dalam proposisi di atas merupakan proposisi PERBANDINGAN, yaitu sikap ayah yang membandingkan anaknya sama dengan robot. Kejadian dalam proposisi KESIMPULAN terdapat dua induk peristiwa, yaitu INDUK 1 dan INDUK 2. Pada INDUK 1 sang anak menyimpulkan bahwa pada saat itu, air laut dalam keadaan sangat dingin seperti es, dan INDUK 2 sang anak menyimpulkan bahwa saat itu banyak ikan buas, seperti ikan gorango dan ikan berduri yaitu ikan tandipang yang sedang mencari mangsa untuk dimakannya.

Proposisi HASIL dibentuk dari hubungan keadaan-HASIL dalam hubungan tersebut sang anak memberi respon secara emosional atas perintahnya ayahnya dengan mengucapkan kalimat emosi sebagai berikut: ja pake ontak sadiki kwak kalu basuru ee!. Jadi proposisi 1 dapat diidentifikasi mengandung pengungkapan kosa kata emosi. Ungkapan itu berbentuk kalimat perintah, yang dalam kalimat itu terdapat kosa kata ontak 'otak, pikiran, logika'; sadiki 'sedikit'. Kosa kata ontak sering dipakai untuk mengungkapkan keadaan emosi. Ontak diidentifikasi sebagai kosa kata 
bagian dari tubuh manusia, khususnya bagian kepala yang sering dirujuk dalam kaitannya dengan emosi.

Analisis data berikut ini adalah analisis hubungan penambahan kronologis. Konsep yang dipakai adalah hubungan waktu yang berurutan dari Larson ${ }^{4}$. Hubungan ini ditandai dengan waktu yang berurutan, kejadian satu mengikuti kejadian lain pada waktu yang berdekatan dan tidak adanya tumpang tindih waktu antar kejadian. Pada topik nomor 2 sebagai berikut memperlihatkan hubungan kronologis.

1) Topik: Ungke Cari Supermi ' Ungke mencari super mi'

\section{Data dalam Bahasa Manado}

Tenga malam, ungke suka mo babli supermie. deng doi 700 pera ditangan. sampe diwarong,

Ungke: Tok, tok, tok, kok, siapa? ungke: Ini unke ko!

Ko' : mo bili apa? ungke: ko' ada supermi rasa kari ayam? Ko' : ada, 1500 pera dp harga ungke: kalo supermi rasa soto ayam? Ko' : ada, 1500

ungke: ko ada yang harga 700 pera? Ko' : ada..supermi rasa tai ayam..!!

\section{Terjemahan dalam Bahasa Indonesia} Tengah malan, Ungke ingin membeli supermi, ia membawa uang 700 rupiah, setibanya di warung...

Ungke: 'Tok, tok, tok kok, siapa?'

Ungke: Ini Unge ko!

Ko: ingin membeli apa?

ungke: ko' ada supermi rasa kari ayam? ko' : ada, 1500 rupiah harganya ungke: kalo supermi rasa soto ayam? ko': ada, 1500 rupiah harganya ungke: ko ada yang harga 700 rupiah? ko' : ada..supermi rasa tai ayam...!

Data no 2

Kalimat (1) pada contoh di atas terdapat empat proposisi, yaitu (1) : Tenga malam, ungke suka mo babili supermi, dengan doi 700 pera di tangan, sampe di warong, (2) tok, tok siapa. (3) Ungke ko, (4) mo bili apa, (5) supermi rasa ayam depe doi 700 pera, (6) ada supermi rasa tai ayang. Skema 4 digambarkan sebagai berikut:

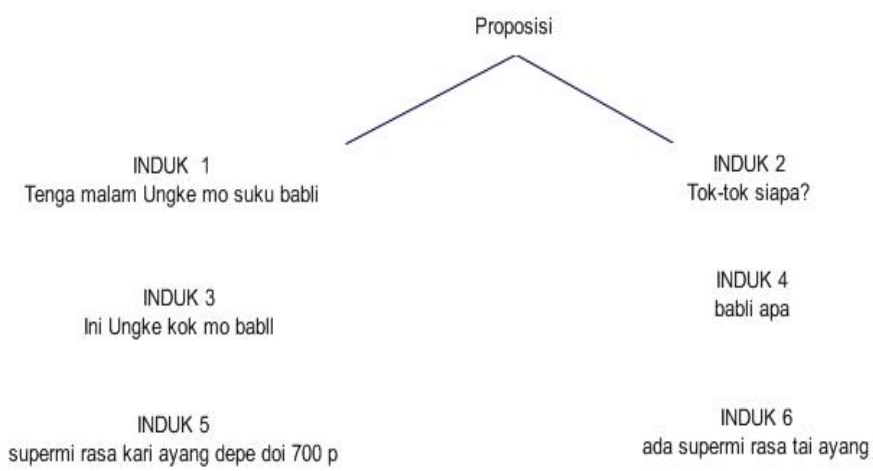

${ }^{4}$ Loc.Cit., Larson. (1984)., hal 291 
Kejadian yang terdapat dalam proposisi di atas berada dalam urutan kronologis, yaitu kejadian pada proposisi pertama diikuti oleh kejadaian dalam proposisi kedua, ketiga, keempat, kelima dan keenam. Selain itu, keenam proposisi di atas dinamakan hubungan penambahan, yaitu hubungan yang satuan -satuan proposisi tersusun membentuk satu prominen sehingga Larson memberi istilah tiaptiap proposisi itu sebaga sebuah INDUK. Kosa kata emosi yang dapat digali dari ungkapan setiap INDUK itu adalah, tai ayang.

\section{Hubungan Kontras -Induk}

Untuk menggali proposisi yang mengandung kosa kata emosi diamati dari dari proposisi yang menunjukkan hubungan kontras-Induk. Untuk keperluan analisis penulisan mengikuti saran Larson (1984) dengan memberi simbol: kontras-INDUK. Untuk mengetahui proposisi kontras-INDUK dapat dilihat pada data nomor 1 dengan topik kesalahan yang disebabkan perhubungan ( guilt), sebagai berikut:

\section{Topik : Popaya 'pepaya'}

Dalam data nomor 2, interaksi antar penutur dan petutur dalam dialog itu dapat diidentifikasi bahwa hubungan antar proposisi menunjukkan hubungan kontras. Hubungan itu dipahami sebagai pola Hubungan kontras-INDUK. Pola hubungan ini terjadi apabila terdapat sebuah titik perbedaan. Satu titik perbedaan dapat terjadi melalui pertentangan (biasanya positif-negatif), dan sebuah kemiripan yang dari segi makna tumpang tindih. ${ }^{5}$ Contoh penggunaan bahasa yang menunjukkan pengalaman afeksi:

Skema 2

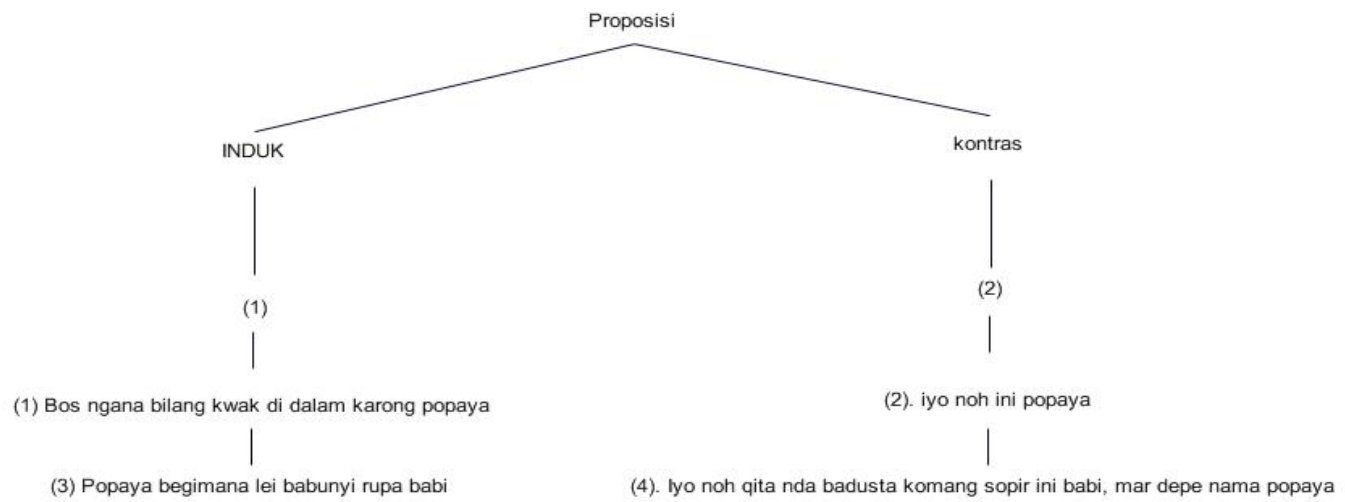

\begin{tabular}{|c|c|c|}
\hline Sopir & $\begin{array}{l}\text { Bos ngana bilang kwa tu di } \\
\text { dalam karong popaya }\end{array}$ & $\begin{array}{l}\text { 'Pak kamu bilang tadi benda } \\
\text { di dalam karung popaya' }\end{array}$ \\
\hline penumpang & Io no ini popaya & 'Benar, ini popaya' \\
\hline Sopir & $\begin{array}{l}\text { Popaya begimana lei babunyi } \\
\text { babi pe suara }\end{array}$ & $\begin{array}{l}\text { 'Popaya } \quad \text { bagaimanakah } \\
\text { bunyinya saja seperti suara } \\
\text { babi' }\end{array}$ \\
\hline
\end{tabular}

${ }^{5}$ Op.cit., Larson 1984., hal 316 
penumpang : ioo noh qita nda badusta komang 'Iya saya tidak bohong sopir.. ini babi mar depe nama kepada pak sopir, babi ini

Data nomor 3 popaya

Pada data nomor 3, terdapat dua titik perbedaan, yaitu sopir 'seorang yang berprofesi sebagai sopir angkutan kota' dan penumpang bernama Alo dan perbedaan melalui pertentangan benda yang ada di dalam karung popaya 'pepaya' dan babi. Selanjutnya, dapat dikatakan bahwa dalam interaksi sopir dan penumpang terdapat kesalahan yang disebabkan perhubungan, penumpang naik angkot dari Wanea Karombasan sampai ke pusat kota, namun sopir berkeberatan bila barang yang dibawa oleh penumpang adalah hewan babi, karena dianggap hewan kotor oleh sopir. Kesalahan perhubungan terjadi karena penumpang berdusta kepada sopir bawa babi dia bilang popaya. Bagi penumpang hal itu bukan kesalahan karena babi itu diberi nama popaya.

Gugus proposisi 2 pada Skema 2 dibentuk oleh hubungan INDUK-kontras untuk menjelaskan dasar munculnya penggunaan kata emosi yang dikatakan sopir kepada salah seorang penumpang mobil angkutan kota yang dikendarainya. Perhubungan kotras ini memiliki satu induk, yaitu INDUK dan kontras. Proposisi INDUK memiliki hubungan yang dibentuk oleh hubungan dasar keadaan kontras, yaitu sopir menginginkan setiap penumpang mobil angkotnya tidak membawa barang yang kotor. Proposisi kontras muncul dari suatu keadaan yaitu penumpang yang membawa hewan babi yang diberi nama popaya. Proposisi INDUK memiliki hubungan kontras-KESIMPULAN. Proposisi kontras berisi tentang tanggapan tanggapan penumpang bahwa yang dibawanya naik ke dalam angkot bukan barang atau hewan kotor, tetapi popaya.

Kata popaya yang ada dalam pikiran sopir bermakna papaya, sedangkan popaya yang ada dalam pikiran penumpang adalah babi. Jadi ada kontras antara buah dan hewan. Kejadian dalam proposisi di atas merupakan proposisi PERTENTANGAN yaitu buah yang rasanya berwarna merah, rasanya manis dengan hewan babi. Kejadian dalam proposisi KESIMPULAN terdapat satu induk peristiwa, yaitu KEADAAN KONTRAS. Pada KEADAAN 1 sang sopir menyimpulkan bahwa pada saat seorang penumpang naik angkotnya tidak membawa barang kotor, hewan seperti babi yang bau, dan kotor, sama halnya dengan ikan yang bau seperti amis, dan KEADAAN 2 penumpang menyimpulkan bahwa saat itu dia hanya membawa popaya, babi yang diberi nama, popaya untuk dijual di pasar pusat kota.

Proposisi HASIL dibentuk dari hubungan keadaan-HASIL dalam hubungan tersebut penumpang angkot merasa berbuat salah kepada sopir, ia respon secara emosional atas perilaku sopir yang sudah menduga dengan benar, bahwa yang dibawa di dalam karung itu adalah babi. hal itu diketahui sopir karena isi dalam karung itu bergerak-gerak dan bersuara mirip suara babi, dengan mengucapkan kalimat emosi sebagai berikut: Popaya begimana lei babunyi babi pe suara. Respon penumpang 
juga dalam keadaan emosi dengan mengucapkan: ioo noh qita nda badusta komang sopir. ini babi mar depe nama popaya.

Jadi proposisi 2 dapat diidentifikasi mengandung pengungkapan kosa kata emosi. Ungkapan itu berbentuk kosa kata yaitu popaya 'pepaya', dan yang dalam kalimat Popaya begimana lei babunyi babi pe suara. Kalimat ioo noh qita nda badusta komang sopir.. ini babi mar depe nama popaya, terdapat kosa kata interjeksi iyo noh 'iya lah'; badusta 'berbohong'. Kosa kata berupa partikel penekan komang 'sungguh benar' sering dipakai untuk mengungkapkan keadaan emosi. Babi diidentifikasi sebagai kosa kata yang merujuk kepada sejenis hewan, khususnya hewan yang dikategorikan kotor, hewan ini yang sering dirujuk dalam kaitannya dengan emosi di kalangan warga masyarakat Manado.

Topik: Bakwartal kalapa

Dalam data nomor 11, adalah kisah monolog dapat diidentifikasi bahwa hubungan antar proposisi menunjukkan hubungan kontras. Hubungan itu dipahami sebagai pola Hubungan kontras-INDUK. Mengikuti konsep Larson (1984), pola hubungan ini terjadi apabila terdapat sebuah titik perbedaan. Satu titik perbedaan dapat terjadi melalui pertentangan (biasanya positif-negatif), dan sebuah kemiripan yang dari segi makna tumpang tindih. ${ }^{6}$ Data itu sebagai berikut:

\begin{tabular}{|l|l|}
\hline Data dalam Bahasa Manado & Terjemahan dalam Bahasa Indonesia \\
\hline ni cirita sekitar taon 2000. & ini cerita sekitar tahun 2000. \\
Satu waktu ni tong pe tamang satu dari & Satu waktu ni tong pe tamang satu dari \\
sanger ...(ungke'), baru ba kwartal & sanger ...(ungke'), baru ba kwartal depe \\
depe kalapa di kampung, jadi cha' ba & kalapa di kampung, jadi cha' ba pasiar \\
pasiar sandiri ka mdo....pe sampe di & sandiri ka mdo....pe sampe di mdo, \\
mdo, langsung maso matahari..(jang & langsung maso matahari..(jang dulu ba \\
dulu ba pikir tu langit ne..), & pikir tu langit ne..), lanjut...disitu cha' \\
lanjut...disitu cha' dapalia tu & dapalia tu pengunjung laeng da babagaya \\
pengunjung laeng da babagaya deng & deng HP. 'Keode' deng dorang,..dong \\
HP. 'Keode' deng dorang,..dong kira & kira cuma dorang tu bole mo dapa \\
cuma dorang tu bole mo dapa bli...kita & bli...kita musti mo bli tu barang \\
musti mo bli tu barang & tudia.......bagitu ni ungke pe pikiran. \\
tudia.......bagitu ni ungke pe pikiran. & \\
\hline
\end{tabular}

Contoh penggunaan bahasa yang menunjukkan pengalaman afeksi dapat digambarkan dalam skema 3 sebagai berikut:

\footnotetext{
${ }^{6}$ Op.cit., Larson 1984., hal 316
} 


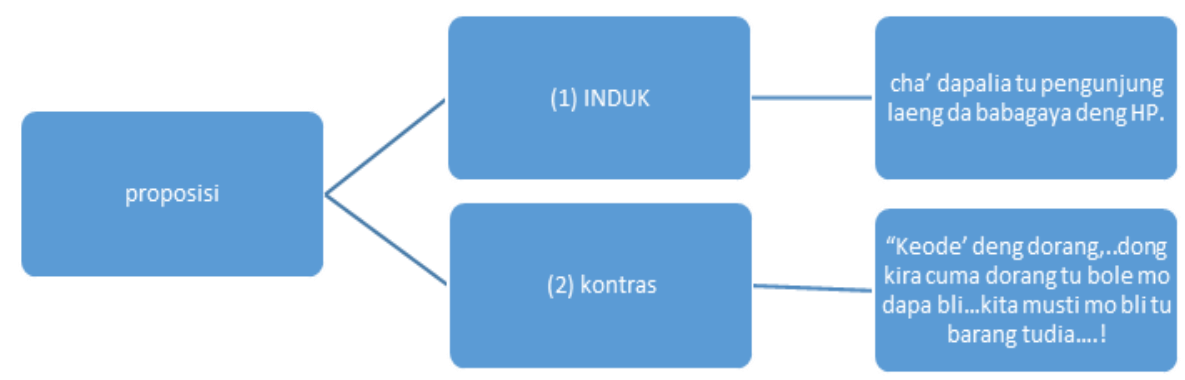

Gugus proposisi 2 pada Skema 3 dibentuk oleh hubungan INDUK-kontras untuk menjelaskan dasar munculnya penggunaan kata emosi yang dikatakan pencerita dalam monolog itu ketika melihat suatu keadaan yang baru dilihatnya. Perhubungan kontras ini memiliki satu induk, yaitu INDUK dan kontras. Proposisi INDUK memiliki hubungan yang dibentuk oleh hubungan dasar keadaan kontras, yaitu Ego berkata dengan dirinya sendiri bahwa ia ingin seperti orang lain memiliki telepon genggam. Proposisi kontras muncul dari suatu keadaan yaitu Ego yang baru saja datang dari Sangir ke Manado ingin membeli teleon genggam. Proposisi INDUK memiliki hubungan kontras-KESIMPULAN. Proposisi kontras berisi keadaan mampu untuk membeli telepon genggam sama seperti yang dipakai kebanyakan orang.

Kata kaode yang ada dalam pikiran Ego bermakna 'ah cuma begitu saya juga bisa'. Jadi, ada kontras antara kenyataan dan harapan. Kejadian dalam proposisi di atas merupakan proposisi PERTENTANGAN yaitu kenyataan belum punya telepon genggam dan harapan untuk dapat memilikinya. Kejadian dalam proposisi KESIMPULAN terdapat satu induk peristiwa, yaitu KEADAAN KONTRAS. Pada KEADAAN 1 Ego belum memiliki telepon, KEADAAN 2 Ego berharap dapat memilikinya. Jadi proposisi 2 dapat diidentifikasi mengandung pengungkapan kosa kata emosi. Ungkapan itu berbentuk kosa kata emosi yaitu kaode 'Cuma itu', kiapa nim bole so.

\section{Hubungan Logis: Pendukung-Induk}

Untuk menggali proposisi yang mengandung kosa kata emosi diamati dari dari proposisi yang menunjukkan hubungan pendukung-Induk. Untuk keperluan analisis penulisan mengikuti saran Larson (1984) dengan memberi simbol: pendukungINDUK. Untuk mengetahui proposisi pendukung-INDUK dapat dilihat pada data nomor 5 dengan topik sebagai berikut:

\section{Topik: Utu Lamu "Utu Banyak Bicara'}

Dalam data nomor 5, interaksi antar penutur dan petutur dalam dialog yang terdapat dalam data nomor 5 itu dapat diidentifikasi bahwa hubungan antar proposisi menunjukkan hubungan logis. Hubungan logis menurut Larson (1984) adalah hubungan yang memiliki satuan pendukung yang mengusulkan satuan induk memberikan alasan, dasar dan lain sebagainya. ${ }^{7}$

${ }^{7}$ Op.cit., Larson, 1984., hal 305 
Hubungan itu merujuk kepada hubungan pendukung-INDUK, yang bersifat non kronologis. Pola hubungan ini terbentuk oleh gagasan sebab-akibat. Dalam hubungan ini komponen utamanya adalah hubungan logis antara proposisi $(x)$ dan proposisi (y) yang mendukung induknya. Dalam data 5 hubungan antar proposisi diidenditifikasi sebagai proposisis yang menunjukkan hubungan logis tipe : alasanHASIL. Analisis data itu sebagai berikut:

Hubungan Logis: Alasan-HASIL

Hubungan Alasan-HASIL merujuk kepada adanya proposisi yang mempunyai peran alasan menjawab pertanyaan, misalnya dalam bahasa Manado : Kiapa depe hasil babagitu dang? 'Mengapa hasilnya begitu saja?' Dalam bahasa bakusedu Manado hubungan ini sering ditandai dengan hadirnya kata, lantarang 'lantaran, depe sebab 'sebabnya', karna 'karena', kong 'maka', jadi 'jadi'.

Contoh:

\section{Skema 4: Hubungan alasan-HASIL}
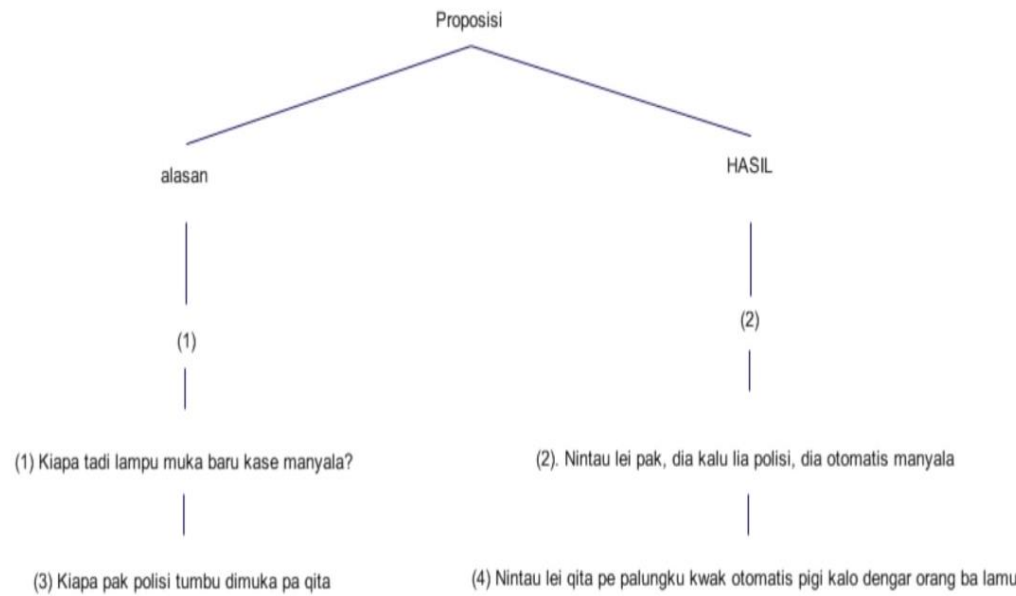

Polisi Selamat siang pak!

Pengendara Siang pak!

motor

Polisi Kiapa tadi lampu muka baru

kase manyala?
Pengendara Nintau lei pak, dia kalo lia polisi,

'Selamat siang pak!'

'Siang pak!'

motor dia otomatis manyala

Polisi Ohh.. kage-kage polisi langsung tumbu di muka pa Utu..Bughh

'Mengapa tadi lampu bagian depan baru dinyalakan?

'Tidak tahu pak, dia kalau melihat polisi, lampu itu otomatis menyala'

Pengendara Eh.. kiapa pak polisi tumbu motor dimuka pa qita?

'Ohh.. tiba-tiba polisi langsung pukul di wajahnya Utu..Bughh'

Polisi Nintahu lei qita pe palungku kwa otomatis pigi kalu dapa dengar orang ba lamu

'Eh.. kenapa pak polisi pukul diwajah saya?'

'Tidak tahulah tangan saya otomatis memukul orang, bila dapat mendengar orang banyak 
bicara'

Contoh dialog dalam data 5 di atas (1) Kiapa tadi lampu muka baru kase manyala? 'Mengapa lampu motor tidak dinyalakan?' menjadi alasan yang menimbulkan HASIL (2) Nintau lei pak, dia kalo lia polisi dia otomatis manyala 'Tidak tahu pak, dia kalau melihat polisi' dengan cara yang serupa tetapi tidak sama dapat diungkapkan sebagai berikut: Kiapa Utu kage-kage kase manyala depe lampu motor? Lantaran dia pe tako dapa tilang polisi. 'Mengapa Utu langsung menyalakan lampu motor? Karena ia taku ditilang polisi'.

Pada data nomor 5, terdapat dua titik yang berbeda, yaitu polisi 'seorang yang berprofesi sebagai polisi' dan pengendara motor bernama Utu. Ketika mengendarai motor Utu tidak menyalakan lampu motornya, tiba di perempatan jalan ada polisi yang sudah mengamatinya. Selanjutnya, dapat dikatakan bahwa dalam interaksi pengendara motor dan polisi terdapat alasan dan hasil. Alasan polisi memberhentikan motor pengendara, karena alasan kelengkapan kendaraan seperti lampu, helm, surat tanda naik kendaraan, serta taat pada rambu-rambu lalu lintas, seperti mengharuskan pengendara motor untuk menyalakan lampu motornya. Utu sebagai pengendara motor menyalahi salah satu aturan itu sehingga polisi memberhentikannya.

Gugus proposisi 2 pada Skema 4 dibentuk oleh hubungan alasan-HASIL untuk menjelaskan dasar munculnya penggunaan kata emosi yang dikatakan pengendara motor kepada salah seorang polisi yang memberhentikan motornya. Perhubungan proposisi $(x)$ dan $(y)$ ini dapat diilustrasikan sebagai $(x)$ yaitu simbol dari sebab yang bertindak sebagai alasan peristiwa, sedangkan (y) adalah simbol dari akibat sebagai perincian pengembangan peristiwanya, yang bertindak sebagai HASIL. Tetapi, dapat pula terbalik akibat atau (y) dijadikan sebagai alasan peristiwa, sedangkan $(x)$ yang bertindak sebagai HASIL.

Proposisi HASIL memiliki hubungan yang dibentuk oleh hubungan dasar keadaan saling berkait, yaitu pengendara motor yang tidak taat peraturan lalu lintas akan mendapat bukti pelanggaran dari polisi. Proposisi saling terkait yaitu sebab akibat muncul dari suatu keadaan yaitu pengendara motor yang melanggar peraturan lalu lintas karena tidak menyalakan lampu. Proposisi alasan memiliki hubungan yang saling terkait, seperti ada alasan-HASIL. Alasan tidak menyalakan lampu motor: Kiapa ngana nyanda kase manyala tu lampu motor? 'Mengapa tidak menyalakan lampu motor?' Nintau lei pak, dia kalo lia polisis, dia otomatis manyala' Tidak tahu pak, dia kalau melihat polisi lampu itu otomatis manyala! Haasil dari berujar seperti itu polisi langsung melakukan tindakan emosi Ohh... kage-kage polisi langsung tumbu di muka pa Utu.. Bughh 'tiba-tiba saja polisi langsung memukul pengendara motor.

Pukulan polisi membuat pengendara motor emosi dengan mengatakan Eh. kiapa pak polisi tumbu dimuka pa qita? 'Mengapa polisi pukul di wajah saya?' . Pengendara motor mendapat pukulan sebagai HASIL dari suatu alasan, yaitu Nintahu lei qita pe palungku kwa otomatis pigi kalu dapa dengar orang ba lamu 'Saya juga 
tidak tahu kepalan tangan saya otomatis langsung pukul orang bila ada orang banyak bicara'

Gugus proposisi 2 pada Skema 4 dibentuk oleh hubungan alasan-HASIL untuk menjelaskan dasar munculnya penggunaan kata emosi yang dikatakan pengendara motor kepada polisi. Perhubungan alasan hasil ini memiliki satu induk, yaitu alasan dan satu hasil. Proposisi alasan memiliki hubungan yang dibentuk oleh hubungan dasar keadaan ada alasan menyebabkan munculnya HASIL. Secara realitas, pengendara motor yang tidak menyalakan lampu akan ditilang, tidak menyalakan lampu motor, menjadi alasan HASIL pengendara motor ditilang oleh polisi. Proposisi alasan muncul dari suatu keadaan yaitu pengendara motor tidak disiplin. Proposisi INDUK memiliki hubungan alasan-HASIL. Proposisi alasan berisi tentang sebab-sebab pengendara motor ditilang.

Ungkapan Kage-kage polisi langsung tumbu di muka pa utu... BUGHHH!! yang dilakukan polisi merupakan ungkapan emosi dalam bentuk kalimat tunggal. Proposisi yang berbentuk kalimat tunggal merupakan ungkapan kebencian. Jadi, kata tumbu 'pukul', di muka 'di wajah', nin tau lei 'saya tidak tahu', palungku 'kepalan tangan' . Kejadian dalam proposisi di atas merupakan proposisi hubungan logis khususnya tentang alasan-HASIL. Kejadian dalam proposisi KESIMPULAN terdapat satu induk peristiwa, yaitu sebab akibat. Pada KEADAAN 1 polisi menyimpulkan bahwa pada saat seorang mengendarai motor lampu harus dinyalakan, hal penyebab muncul emosi, proposisinya: Kiapa tadi lampu muka baru kase menyala? dan KEADAAN 2 pengendara motor merasa tidak bersalah dan emosi juga dengan mengatakan: Utu: nintau leh pak, dia kalo lia polisi, dia otomatis manyala.

Topik: Pulang skola

Dalam data nomor 12, interaksi antar penutur dan petutur dalam dialog yang terdapat dalam data nomor 12 itu dapat diidentifikasi bahwa hubungan antar proposisi menunjukkan hubungan logis. Hubungan logis menurut Larson (1984) adalah hubungan yang memiliki satuan pendukung yang mengusulkan satuan induk memberikan alasan, dasar dan lain sebagainya. ${ }^{8}$

Hubungan itu merujuk kepada hubungan pendukung-INDUK, yang bersifat non kronologis. Pola hubungan ini terbentuk oleh gagasan sebab-akibat. Dalam hubungan ini komponen utamanya adalah hubungan logis antara proposisi $(x)$ dan proposisi (y) yang mendukung induknya.

Hubungan Logis : sebab-akibat

Dalam data 13 hubungan antar proposisi diidenditifikasi sebagai proposisi yang menunjukkan hubungan logis tipe : alasan-HASIL. Analisis data itu sebagai berikut:

Bahasa Manado

P1 Butul ngana dari sekolah kalo bagitu opa mau tes dulu pa ngana.!"

P2 Tes jo.!”
Bahasa Indonesia

'betul kamu ke sekolah hari ini?

Opa tes dulu'

'Silakan tes'

${ }^{8}$ Op.cit., Larson, 1984., hal 305 
P1 Kalo $10 \times 10$ berapa dang? klo ngana dari sekolah paling ngana tau..!

P2 Ado opa talalu banyak kita pe tangan nyanda sampe mo bahitung, ado kita nintau..!

P1 Ngana memang bodok masa bagitu le nintau mulai besok ngana brenti jo sekolah bekeng abis doi jo ngana..!"

Oma napa opa ada ba marah pa kita..!

"Napa alo p biongo masa dari sekolah nintau 10×10, bekeng abis doi jo dia sekolah lebe bae berenti sekolah kong ba jual kukis pisang tau-tau dapa doi.."
' Kalau 10x10 berapa kalau kamu ke sekolah kamu tahu itu'

'Aduh opa terlalu banyak kita pe tangan nyanda sampe saya tidak tahu'

'kalau begitu kamu bodoh lebih bak berhenti sekolah bikin habis uang saja.

'Oma lihat in opa marah kepada saya'

'Liha ini ALo bodoh dia tidak dapat berhitug 10x10, bikin habis uang saja dia ke sekolah, suruh jual pisa saja jelas di dapat uang'

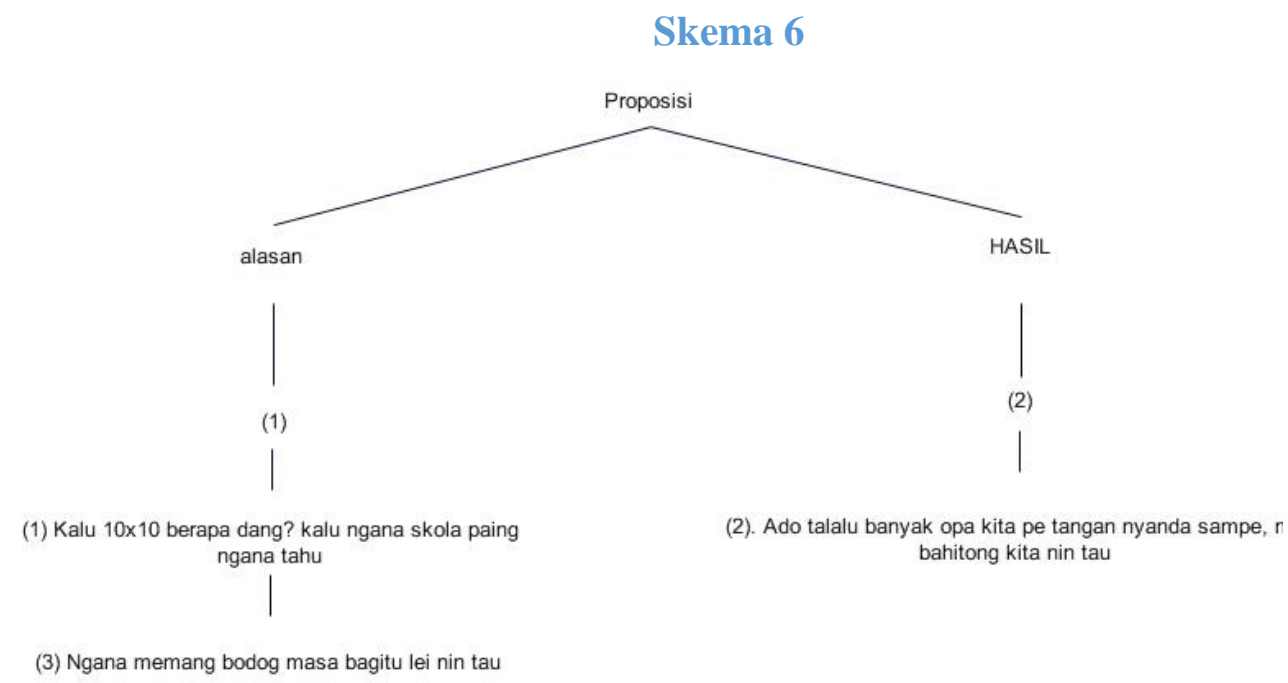

Pada data nomor 13, terdapat dua titik yang berbeda, yaitu opa 'kakek' bertindak sebagai guru dan cucunya bernama Alo. Ketika pulang sekolah ditanya pelajaran oleh kakeknya. Selanjutnya, cucu itu tidak dapat menjawab pertanyaan sang opa. Situasi itu mengindikasikan ada alasan dan hasil. Alasan Alo tidak dapat menjwab pertanyaan opa, karena alasan tangannya tidak cukup untuk menghitung.

Gugus proposisi 2 pada Skema 6 dibentuk oleh hubungan alasan-HASIL untuk menjelaskan dasar munculnya penggunaan kata emosi yang dikatakan opa kepada cucunya. Perhubungan proposisi $(x)$ dan (y) ini dapat diilustrasikan sebagai (x) yaitu simbol dari sebab yang bertindak sebagai alasan peristiwa, sedangkan (y) adalah simbol dari akibat sebagai perincian pengembangan peristiwanya, yang bertindak sebagai HASIL. Tetapi, dapat pula terbalik akibat atau (y) dijadikan sebagai alasan peristiwa, sedangkan $(x)$ yang bertindak sebagai HASIL. Proposisi 
HASIL memiliki hubungan yang dibentuk oleh hubungan dasar keadaan saling berkait, yaitu cucu tidak dapat menjawab pertanyaan dari opa. Proposisi saling terkait yaitu sebab akibat muncul dari suatu keadaan yaitu sang opa emosi. Proposisi alasan memiliki hubungan yang saling terkait, seperti ada alasan-HASIL.

Gugus proposisi 2 pada Skema 6 dibentuk oleh hubungan alasan-HASIL untuk menjelaskan dasar munculnya penggunaan kata emosi yang dikatakan kakek kepada cucunya. Perhubungan alasan hasil ini memiliki satu induk, yaitu alasan dan satu hasil. Proposisi alasan memiliki hubungan yang dibentuk oleh hubungan dasar keadaan ada alasan menyebabkan munculnya HASIL. Secara realitas, cucu yang tidak dapat menjawab pertanyaan tentang hitungan matematika menjadi alasan HASIL kakek menjadi emosi. Proposisi alasan muncul dari suatu keadaan yaitu cucu yang bernama Alo tidak belajar matematika dengan baik. Proposisi INDUK memiliki hubungan alasan-HASIL. Proposisi alasan berisi tentang sebab-sebab kakek marah kepada cucunya.

Ungkapan Tau no nga kira kita biongo rupa alo..! 'Tahulah kamu kira saya bodoh seperti Alo' yang dilakukan opa atau kakek merupakan ungkapan emosi dalam bentuk kalimat tunggal. Proposisi yang berbentuk kalimat tunggal merupakan ungkapan 'hilang harapan'. Jadi, kata biongo 'tolol', bodok 'bodoh', nin tau lei 'saya tidak tahu'. Kejadian dalam proposisi di atas merupakan proposisi hubungan logis khususnya tentang alasan-HASIL. Kejadian dalam proposisi KESIMPULAN terdapat satu induk peristiwa, yaitu sebab akibat. Pada KEADAAN 1 kakek menyimpulkan bahwa pada bila sekolah tidak pandai lebih baik berdagang saja, hal penyebab muncul emosi, proposisinya : Ado opa talalu banyak kita pe tangan nyanda sampe mo ba hitung, ado kita nintau..! dan KEADAAN 2 pengendara motor merasa tidak bersalah dan emosi juga dengan mengatakan: Ngana memang bodok masa bagitu le nintau mulai besok ngana brenti jo sekolah bekeng abis doi jo ngana..!"

\section{Analisis Penggunaan Kata yang Menggambarkan Pengalaman Afeksi}

Makna afeksi yang dimaksud dalam kajian ini, khususnya dalam konteks dialog adalah makna yang muncul dari ujaran yang disampaikan penutur kepada mitra tutur. Untuk menganalisis pengalaman afeksi digunakan klasifikasi kawasan afeksi sebagaimana disarankan oleh Gray (2002).

\section{Pengalaman Afeksi Pada Tingkat Penerimaan}

Pada tingkat ini melihat tingkatan: penerimaan dengan dicirikan dengan ada kata kerja: mendengarkan, memperhatikan dan menyetujui. Data berikut ini, mitra tutur memberi respon terhadap penggunaan bahasa dalam dimensi rasa. Contoh: Topik: Pulang Skola

\section{Bahasa Manado}

1. P1 maa, napa kita oto kijang ada sambar di jalang tadi..!

2. P2 kong dang...?

3. P1 kong tu tuang oto turun kong dia
Bahasa Indonesia

'ma saya terserempet mobil kijang di jalan tadi'

'lalu apa yang terjadi selanjutnya?'

'lalu pemilik mobil itu turun 
kase serattus ribu pa kita...

4. $\mathrm{P} 2$ oh, mar ngana nyanda apa-apa to alo?

5. P1 nda noh..

6. N depe besok. pas alo pulang skola, dia lia depe mama ada ditenga jalang ada pele oto

7. P1 Ado kasiang FUSO itu mama

8. P2 Badiam ngana anak, juta ini sambil memberi uang seratus ribu kepada saya..'

'oh, tapi kamu baik-baik saja kan?

'ya saya baik-baik saja'

'keesokan harinya, ketika Alo pulang sekolah. Dia lihat ibunya sedang berdiri di tengah jalan sedang menghalangi jalannya mobil fuso'

'Hati-hati bu, ada mobil fuso'

'Diamlah kamu anak, ini juta'

Data nomor 4

Keterangan: $\mathrm{P} 1=$ penutur $1 ; \mathrm{P} 2=$ penutur 2 dan $\mathrm{N}=$ narrator

Kalimat no (1) dan (2) mengandung makna yang berhubungan dengan perasaan yang hadir sesudah seorang penutur bahasa (disebut P1) menyampaikan pengalamannya di jalan. Mitra tuturnya (disebut P2) mendengarkan, dan memperhatikan apa yang disampaikan P1. Memperhatikan peristiwa yang dialami P1, P2 merasa kwatir, sehingga ia mengungkapkan ujaran: kong dang? yang mengindikasikan keadaan mendengar bercampur rasa khawatir. Kekhawatiran itu hilang, ketika P1 mengatakan nda noh 'saya baik-baik saja'. Kridalaksana (1984) mengemukakan afeksi adalah gaya atau makna yang menunjukkan perasaan. ${ }^{9}$ Berangkat dari konsep tersebut pengalaman afektif dikaitkan dengan ungkapan perasaan emosi dalam bakusedu dicirikan dengan kata kong dang, nda noh. Pada kalimat (8) dan (9) diidentifikasi sebagai kawasan afeksi pada tingkat penerimaan. P1 mengujarkan: ado kasiang itu fuso mama, 'hati-hati ada mobil bu', P2 menjawab: badiam ngana anak, juta ini 'diam saja kamu saya akan mendapat uang juta ini'. P1 tidak berkata apa-apa lagi, tanda menyetujui apa yang dilakukan oleh P2. Kata emosional yang diungkapkan adalah badiam.

\section{Pengalaman Afeksi Pada Tingkat Tanggapan}

Pengalaman afeksi tingkat tanggapan memiliki ciri yang menggunakan kata kerja menanggapi, mencatat, dan menghargai. Contoh dalam data: Topik: Ungke deng nona da baku sms

Bahasa Manado

9. Sayang ada bekeng apa doe

10. Nda cuma da dudu

11. Kiapa nda balas dang

12. Ada noh kita da balas

13. Ngana so ada laeng kang?
Bahasa Indonesia

'Sayang sedang apa'

'Tidak, cuma duduk'

'Mengapa tidak balas'

'Saya sudah balas'

'Kamu sudah ada lain?'

${ }^{9}$ Harimurti Kridalaksana. Kamus Linguistik. (Jakarta: Gramedia, 1984)., hal 2 
14. Nda noh kita cuma sayang pa ngana

15. O jadi so nda sayang pa kita dang

16. Pendo leh

Data nomor 9

Dalam data nomor 9 di atas merupakan dialog yang menggambarkan kawasan afektif yang menggambarkan perasaan pribadi penyapa (P1) terhadap pesapa (P2). Kalimat nomor (9-10) menunjukkan adanya tindakan memberi tanggapan. P1 bertanya P2 menanggapi. Dialog P1 dan P2 saling melibatkan perasaan 'saling mencintai', tetapi pada kalimat nomor (13) mulai ada perasaan 'cemburu kepada orang lain yang tidak dikenal'. Kalimat nomor (16) adalah kalimat berupa sebuah kata pendo 'kemaluan laki-laki', menunjukkan orang yang dianggap rendah sehingga martabatnya disamakan dengan hal yang ditunjukkan itu. Kata 'pendo' tersebut memiliki nilai rasa yang berhubungan tidak menghargai orang lain.

\section{Pengalaman Afeksi Pada Tingkat Penilaian}

Pengalaman afeksi tingkat penilaian memiliki ciri yang menggunakan kata kerja mengenali, memutuskan, menilai, dan mempengaruhi. Contoh dalam data:

Topik: Barol

17. Heh, biongo!

18. Ngana ini cuma da ta putar-putar sama deng babi pa de pe kandang. Co ngana lia ni ngana pe diri ni dia...

19. Co ngana lia ni ngana pe diri ni dia...

Ngana

pe

hidop...

Samua tu ngana ja baking, nyanda ada yang barguna.

20. Ngana pe hidop ni dia cuma da abis-abis di mengkhayal jo.

21. Ngana so beking pastiu pa kita!!! Ngana pangge-pangge pa kita bermain tentang tu rahasia...kong, saban torang somo dapa depe klimaks...ngana user pa kita.

22. Salalau bagitu.

23. Salalu...salalu...memang jago ngana...

boleh beking kalah pa kita... Mar baru ngana le kwa tu da se kalah pa kita no.

24. Sapa ngana sebenarnya?
'Heh, orang bodoh'

'Kamu ini Cuma putar-putar sama saja dengan babi yang ada di kandang. Lihatlah dirimu sendiri.'

'Coba kamu lihat dirimu. Dalam menjalankan hidupmu, apa saja yang kamu buat itu tidak berguna.'

'Setiap hari kerjamu hanya menghayal saja'

'Kamu bikin saya benci. Kamu selalu saja mengajak saya bermain dengan rahasia itu, setiap kali sudah sampai pada klimaks, kamu usir saya'

'Selalu begitu '

'Selalu-selalu memang jago kamu... apakah kamu dapat mengalahkan saya, tapi baru kamu saja memang yang dapat mengalahkan saya'

'Siapa kamu sebenarnya' 
Dalam data nomor 10 di atas merupakan dialog yang menggambarkan kawasan afektif tingkat penilaian. Dalam dialog itu penutur (P1) berbicara kepada mitra tutur (P2). Kalimat nomor (17-24) menunjukkan adanya tindakan P1 yang memberi penilaian kepada P2 secara emosional. P1 menilai, namun P2 diam saja. Dia menerima penilaian itu. Dialog P1 dan P2 bersifat satu arah. Kalimat nomor (17), merupakan ungkapan emosi P1: Heh biongo 'Heh orang bodoh', demikian pula kalimat pada nomor (18): Ngana ini Cuma da ta putar-putar sama deng babi pa de pe kandang 'Kamu ini Cuma putar-putar sama saja dengan babi yang ada di kandangnya'. Kalimat (17) dan (18) menunjukkan bahwa P1 mengenali P2, kemudian P1 menilai segala perilaku P2, ungkapan menilai dilakukan secara emosi.

Kalimat 21, menunjukkan bahwa P1 memutuskan bahwa P2 telah melakukan tindakan yang membuat P1 merasa benci dengan ungkapan: Ngana so beking pastiu pa kita! Ngana pangge-pangge pa kita bermain tentang tu rahasia.. Kong saban torang somo dapa depe klimaks... ngana user pa kita 'Kamu bikin saya benci. Kamu selalu saja mengajak saya bermain dengan rahasia itu, setiap kali sudah sampai pada klimaks, kamu usir saya.

Kalimat 22, menunjukkan bahwa P1 mempengaruhi bahwa P2. P1 mengatakan: salalu...salalu memang jago ngana... boleh beking kalah pa kita, mar baru ngana le Kwa tu da se kalah pa kita! 'Selalu...selalu saja kamu yang hebat, kamu bisa mempengaruhi saya' Sapa ngana sebenarnya? Kalimat 23 diungkapkan P2, Siapa kamu sebenarnya? Pada kalimat 23 P2 melakukan belum mengenali P1, ungkan belum kenal dilakukan dengan cara bertanya.

\section{Analisis Hubungan Antarproposisi}

Pada data yang dianalisis yaitu data nomor 1, 2, 3, 4, 9,10, 11, 12, dan13 dapat diidentifikasi dari sudut pandang sosiologi sebagai suatu interaksi antar manusia satu dengan manusia lainnya, artinya ada interaksi sosial. Dalam Kamus Besar Bahasa Indonesia, interaksi didefinisikan sebagai 'saling melakukan aksi, berhubungan, mempengaruh'. ${ }^{10}$ Dengan begitu, interaksi sosial dapat diartikan sebagai hubunganhubungan social yang bersifat dinamis yang bertalian dengan hubungannatarindividu, individu dan kelompok, atau antarkelompok.

Maryati (2004) mengemukakan bahwa dalam hubungan interaksi sosial ada tiga tipe, yaitu: a) bekerja sama, atau terjadi konflik; b) hubungan formal atau nonformal; c) hubungan langsung atau tak langsung. Contoh ujaran dalam bakusedu:

Bahasa Manado

Alo: Cewe boleh tanya mar jang marah neh..?

Cewe: mo tanya apa om?

Alo: ehhmm.. nti qta kase doi $50 \mathrm{rb}, \ldots$
Bahasa Indonesia

Alo: Cewe boleh tanya tetapi jangan marah ya

Cewe: Ingin bertanya apa om?

Alo: ehhmm.. nanti saya beri uang lima

${ }^{10}$ Tim Penyusun. 2014. Kamus Besar Bahasa Indonesia. (Jakarta: Gramedia, 2014), hal 543 
mar boleh mo pegang ngana pe dada?

Cewe: pe badengar tu om pe katakata dia langsung Nae darah. Iihh.. gila stow ngana kang Om?? nda warwar stow...! puluh ribu rupiah tetapi bolehkan saya memegang dadamu?

Cewe: ketika mendengar kalimat itu dia langsung naik darah. Iihh.. barangkali om omo gila, Anda gila ya? Anda tidak waras..!!

\section{Data 15}

Data tersebut di atas, terlihat bahwa dalam interaksi social terjadi hubungan timbal balik, yaitu P1 'Alo' dan P2 'Cewe' yang melibatkan aspek sosial dan kemanusiaan kedua belah pihak, seperti emosi. Ungkapan emosi terdapat pada ungkapan iih gila stow. Mengapa ungkapan emosi ini terjadi? Ungkapan emosi terjadi karena di dalam interaksi salah satu pihak memberikan stimulus atau aksi dan pihak lain memberikan respon atau reaksi. Contoh: cewe bole mo tanya mar jang mara neh? 'cewe boleh tanya, tapi jangan marah ya'; Tanya apa om? 'tanya apa om?' Boleh mo pegang ngana pe dada? 'Boleh pegang dadamu'. Tindakan yang dilakukan oleh P2 yang marah terhadap P1 dikatakan sebagai tindakan afektif. Menurut Weber dalam Murdiyatmoko (2004) mendefinisikan bahwa tindakan afektif (affectual action) merupakan tindakan yang dipengaruhi oleh perasaan atau emosi. ${ }^{11}$ Tindakan ini seringkali dilakukan tanpa perencanaan matang dan tanpa kesadaran penuh. Luapan perasaan marah, cinta, ketakutun gembira dan ungkapan-ungkapan perasaan spontan seseorang yang dilakukan tanpa pertimbangan akal budi dan kesadaran penuh menunjukkan bahwa orang itu sedang menunjukkan tindakan efektifnya. Bertumpu pada konsepsi di atas dapat digambarkan bahwa penggunaan kosa kata emosi dalam bakusedu dapat digambarkan sebagai berikut:

Tabel 2 Kosa Kata/Frase/ Ungkapan Emosi Negatif dalam Bakusedu

\begin{tabular}{|l|l|l|r|}
\hline & $\begin{array}{l}\text { Kosa kata/frase/ ungkapan } \\
\text { emosi } \begin{array}{r}\text { negatif } \\
\text { bakusedu Manado }\end{array}\end{array}$ & Gambaran afeksi & Data nomor \\
\hline 1 & /tumbu di muka/ & 'kemarahan' & 1 \\
\hline 2 & /nin tau lei/ & 'putus asa' & 1 \\
\hline 3 & /lamu/ & 'benci' & 2 \\
\hline 4 & /gila stow/ & 'mungkin gila' & 2 \\
\hline 5 & /nda war-war/ & 'tidak punya perasaan malu' & 2 \\
\hline 6 & / so ba lombo dia/ & 'perasaan bersalah hilang' & 2 \\
\hline 7 & /bale bingo/ & 'perasaan ketakutan' & 7 \\
\hline 8 & /besae/ & 'perasaan hina' & 8 \\
\hline 9 & /manalu lai/ & 'perasaan malu' & \\
\hline 10 & /lonte/ & 'perasaan tak suka dengan & \\
\hline
\end{tabular}

${ }^{11}$ Murdiyatmoko, Janu. Sosiologi. (Jakarta: Grafindo, 2004)., hal 51. 


\begin{tabular}{|l|l|l|r|}
\hline & & suatu profesi' & \\
\hline 11 & /bingo yaki/ & 'ketakutan' & 9 \\
\hline 12 & /takage/ & 'rasa ngeri' & 9 \\
\hline 13 & /kaode/ & 'benci' & 9 \\
\hline 14 & /biongo/ & 'bersalah' & 9 \\
\hline 15 & /puih bo/ & 'jijik' & 10 \\
\hline 16 & /soe deng ngana/ & 'perasaan benci' & 15 \\
\hline 17 & /kiapa lei hah/ & 'marah-marah' & 17 \\
\hline
\end{tabular}

Tabel 3 Kosa Kata/Frase/ Ungkapan Emosi Positif dalam Bakusedu

\begin{tabular}{|l|l|l|l|r|}
\hline & $\begin{array}{l}\text { Kosa } \\
\text { ungkapan } \begin{array}{r}\text { kata/frase/ } \\
\text { emosi } \\
\text { positif } \\
\text { bakusedu Manado }\end{array}\end{array}$ & $\begin{array}{l}\text { Makna dalam } \\
\text { bahasa Indonesia }\end{array}$ & Gambaran afeksi & $\begin{array}{l}\text { Data } \\
\text { nomor }\end{array}$ \\
\hline 1 & /pasung/ & 'cantik' & 'perasaan gembira' & 8 \\
\hline 2 & /gaga/ & 'cantik, ganteng' & 'rasa gembira' & 8 \\
\hline 3 & /o nyanda komang/ & 'o baiklah' & 'rasa berminat' & 16 \\
\hline 4 & /babuju/ & 'membujuk' & 'agak gembira' & 1 \\
\hline 5 & /noh bole jo/ & 'itu bagus' & 'perasaan berminat' & 4 \\
\hline 6 & /o memang kote/ & 'o begitu ya' & 'gembira' & 6 \\
\hline 7 & /kage jaha/ & 'terkejut sekali' & 'sangat gembira' & 18 \\
\hline
\end{tabular}

Tabel 4 Kosa Kata/Frase/ Ungkapan Emosi Netral dalam Bakusedu

\begin{tabular}{|c|c|c|c|c|}
\hline & $\begin{array}{lr}\text { Kosa } & \text { kata/frase/ } \\
\text { ungkapan } & \text { emosi } \\
\text { netral dalam bakusedu } & \\
\text { Manado } & \end{array}$ & $\begin{array}{l}\text { Makna dalam } \\
\text { bahasa Indonesia }\end{array}$ & Gambaran afeksi & $\begin{array}{l}\text { Data } \\
\text { nomor }\end{array}$ \\
\hline 1 & /pastiyul & 'bosan' & 'perasaan bosan' & 18 \\
\hline 2 & /kiapa so/ & 'mengapa begitu' & 'perasaan heran' & 18 \\
\hline 3 & /herang no/ & 'heran' & 'perasaan heran' & 18 \\
\hline
\end{tabular}

Dari table 2, 3, dan 4 diperoleh kosa kata emosi dalam bakusedu berjumlah 10, sedangkan dalam bentuk frase berjumlah 17 buah. Kosa kata emosi negatif muncul karena dalam interaksi P1 dan P2 terjadi konflik. Konflik adalah suatu proses sosial ketika orang perorangan atau kelompok manusia berusaha untuk memenuhi kebutuhannya disertai ancaman atau kekerasan. Sebab-sebab konflik yang muncul dalam bakusedu itu, antara lain: 1) ada perbedaan antara orang perorangan, misalnya dalam perbedaan pendirian dan perasaan; 2) perbedaan pola pikir yang dapat menyebabkan pertentangan antar orang perorangan. 


\section{Penggunaan Kosa kata yang Menggambarkan Pengalaman Afeksi}

Hasil analisis penggunaan kosa kata bahasa Manado dalam bakusedu sebagaimana telah dibahas di atas menunjukkan realitas sosial kehidupan bersama, manusia memerlukan aturan hidup. Aturan hidup itu diterapkan agar tercipta keteraturan social. Data di dalam bakusedu menunjukkan bahwa ada aturan hidup yang tidak selalu diwujudkan secara nata, atau tidak melakukan hal tertentu. Ada perasaan-perasaan tertentu jika orang melakukan. Walaupun terlihat abstrak, tetapi dapat dirasakan manfaatnya, bahkan ada yang dapat dihayati. Misalnya pada data 19, berikut ini:

\begin{tabular}{|c|c|c|}
\hline & Bahasa Manado & Bahasa Indonesia \\
\hline P3 & $\begin{array}{l}\text { Waktu opo da baca koran, Susi } \\
\text { depe bini bage deng sondo dari } \\
\text { balakang! }\end{array}$ & $\begin{array}{l}\text { sang istri memukulnya dengan sendok } \\
\text { besar dari belakang' }\end{array}$ \\
\hline $\mathrm{P} 1$ & $\begin{array}{l}\text { Kiapa ngana so? Kiapa kita pe } \\
\text { kapala so dapa pukul? }\end{array}$ & $\begin{array}{l}\text { 'Kenapa kamu berbuat itu? Mengapa } \\
\text { kepala saya dipukul?' }\end{array}$ \\
\hline $\mathrm{P} 2$ & $\begin{array}{l}\text { Eh, tadi kita da bacuci ada dapa } \\
\text { kertas pa ngana pe calana. Ada } \\
\text { tulis Rina, ngana pe hugel kang? }\end{array}$ & $\begin{array}{l}\text { 'Eh, tadi saya sedang mencuci baju kamu } \\
\text { saya dapatkan kertas di kantong } \\
\text { celanamu. Ada tulisan nama seorang } \\
\text { wantia bernama Rina, dia selingkuhan } \\
\text { kamu ya?' }\end{array}$ \\
\hline $\mathrm{P} 1$ & $\begin{array}{l}\text { Oooooohhh...itu... inga toh, kita } \\
\text { pernah balomba pacuan kuda di } \\
\text { Tompaso minggu lalu? Rina itu } \\
\text { depe nama kuda. Kita bataruh } \\
\text { for tu kuda itu! }\end{array}$ & $\begin{array}{l}\text { 'ooh ..itu inget kan, kita pernah ikut } \\
\text { lomba pacuan kuda di Tompaso minggu } \\
\text { lalu? Rina itu nama seekor kuda. Saya } \\
\text { menunggang kuda itu! }\end{array}$ \\
\hline P3 & $\begin{array}{l}\text { Susi dapa rasa puas dengan opo } \\
\text { pe jawaban. Dia minta maaf pa } \\
\text { opo kong momasa ulang di } \\
\text { dapur. Depe beso opo babaca } \\
\text { korang ulang di ruang tamu. } \\
\text { Diam-diam Susi badekat kong } \\
\text { bage opo pe kapala deng } \\
\text { balanga. Plak! }\end{array}$ & $\begin{array}{l}\text { 'Susi merasa puas dengan penjelasan } \\
\text { opo. Dia minta maaf kepada opo lalu } \\
\text { melanjutkan kerjanya memasak di dapur. } \\
\text { Keesokan harinya, opo membaca korang } \\
\text { di ruang tamu. Diam-diam Susi mendekat } \\
\text { lalu memukul opo punya kepada dengan } \\
\text { penggorengan. Plak! }\end{array}$ \\
\hline $\mathrm{P} 1$ & Kiapa, lei hah? & 'Kenapa lagi kamu \\
\hline $\mathrm{P} 2$ & Tadi ngana pe kuda batelepon! & 'tadi kudamu menelpon! \\
\hline
\end{tabular}

Data 19 menceritakan P1 berselingkuh dengan seorang wanita muda, selain istrinya. Perselingkuhan itu diketahui sang istri karena perempuan itu menelpon. Meskipun P1 tidak merasa berselingkuh atau merasa bersalah, bagi P2 persaan marah menjadi muncul karena ada perilaku yang tidak beres. Perilaku berselingkuh inilah 
yang disebut nilai sosial yang menyebabkan munculnya penggunaan kosa kata emosi yang digunakan oleh P2 kepada P1.

Berangkat dari data itu, pendapat Lawang (1984) dapat dirujuk. Ia menyebutkan bahwa nilai sosial adalah gambaran mengenai apa yang diinginkan, yang pantas, yang berharga, yang mempengaruhi perilaku sosial dari orang yang memiliki nilai itu ${ }^{12}$. Konsep ini mengindikasikan bahwa nilai erat hubungannya dengan kebudayaan dan masyarakat. Setiap masyarakat atau setiap kebudayaan memiliki nilai-nilai tertentu mengenai sesuatu. Kebudayaan dan masyarakat itu sendiri merupakan nilai yang sangat berharga bagi orang yang memilikinya.

Koentjaraningrat (1990) menjelaskan bahwa sistem nilai budaya adalah konsep-konsep yang hidup dalam pikiran sebagian besar warga masyarakat, mengenai hal-hal yang harus mereka anggap amat bernilai dalam hidup, dan biasanya berfungsi sebagai pedoman tertinggi bagi kelakuan manusia, yang dijabarkan dalam bentuk konkret berupa aturan-aturan, norma-norma, atau hukum yang mengatur perilaku tiap anggota masyarakat.

Penggunaan kosa kata, frase, ungkapan emosi yang terdapat dalam baku sedu, seperti dalam data 20: soe pe soe lei 'sial sungguh sangat sial'; eh biongo 'eh bodoh' merupakan nilai-nilai social yang memiliki ciri-ciri, antara lain sebagai berikut: 1) ujaran emosi yang terdapat dalam bakusedu baik itu emosi (negatif, netral, positif) merupakan konstruksi masyarakat yang tercipta melalui interaksi antaranggota; 2) penggunaan kosa kata emosi itu dapat mempengaruhi perkembangan pribadi dalam masyarakat, baik secara positif maupun negatif. Uraian di atas menunjukkan bahwa bakusedu Manado memiliki nilai sosial yang berfungsi, antara lain: 1) bakusedu merupakan piranti solidaritas di kalangan anggota masyarakat Manado; 2) bakusedu dapat berfungsi sebagai arah berpikir dan bertingkah laku secara baik di dalam masyarakat; 3) bakusedu dapat berfungsi sebagai alat pengawas dengan daya pengikat tertentu, nilai ini memiliki daya dorong menuntuk dan menekan manusia untuk berbuat bagi.

\section{Kesimpulan Dan Saran}

Kesimpulan

Berangkat dari analisis dan pembahasan hasil-hasil penelitian ini, maka dapat ditarik kesimpulan sebagai berikut:

1. Hubungan antarproposisi merupakan objek penting pada penelitian penggunaan kosa kata yang menggambarkan pengalaman afeksi yang digali melalui proposisi pada monolog dan dialog bakusedu. Hubungan antarproposisi penambahan dan pendukung digunakan untuk menjelaskan satu peristiwa denga peristiwa lain yang saling berkaitan dalam sebuah wacana bakusedu. Melalui analisis proposisi yang telahdilakukan, yaitu analisis hubungan antar proposisi dan analisis penggunaan kosa kata emosi

${ }^{12}$ Lawang, Robert MZ. Pengantar Sosiologi. (Jakarta: Universitas Terbuka, 1984)., hal 84 
dalam proposisi ditemukan bahwa 10 kosa kata emosi dan 17 frase yang mengungkapkan makna emosi.

2. Ditinjau dari penggunaan kosa kata emosi yang terdapat di dalam bakusedu itu terkandung adanya perbedaan penggunaan bahasa. Perbedaan penggunaan bahasa berkaitan dengan nilai sosial, sebab nilai sosial dapat mempengaruhi emosi dan perkembangan pribadi di dalam masyarakat bai secara positif maupun negatif.

\section{Saran}

Berdasarkan kesimpulan hasil penelitian yang dipaparkan di atas, peneliti menyarankan bahwa penelitian terkait proposisi dan monolog atau dialog yang menggunakan bahasa daerah dalam penelitian linguistik menarik untuk ditelaah. Lebih menarik lagi, bila dihubungkan dengan persoalan adanya penggunaan ungkapan emosi, karena sering emosi merupakan suatu aspek yang diungkapkan secara langsung dalam satuan proposisi. Penelitian ini merupakan bentuk temuan awal. Banyak aspek-aspek yang barangkali perlu diperbaiki, disempurnakan bahkan dilanjutkan oleh peneliti berikutnya. Melalui penelitian bakusedu dengan cakupan yang berbeda dengan ruang lingkup penelitian ini dimungkinkan dapat dijelaskan generalisasi penggunaan kosakata emosi yang menggambarkan pengalaman afeksi dari sudut pandang yang berbeda. Sebagai suatu bentuk kajian linguistik interdisiplin, model penelitian ini masih menyediakan banyak persoalan yang dapat dicermati dan diungkap lebih lanjut, khusunya terkait dengan interaksi sosial dalam bentuk penggunaan bahasa monolog dan dialog. 


\section{DAFTAR PUSTAKA}

Cumming, R. 1989. Meaning and Mental Representation. Cambridge: Cambridge University Press

Komala, Sonya Ayu. 2012. "Pengungkapan Karakter Dalam Proposisi Analisis Wacana Naratif Seorang Aktivis", Depok: TEsis FIB UI

Lawang, Robert MZ.1984 Pengantar Sosiologi. Jakarta: Universitas Terbuka

Larson, Mildred, L. 1984. Penerjemahan Berdasar Makna: Pedoman untuk Pemadanan Antarbahasa. Kencanawati Tamiran Penerjemah. Jakarta: Arcan

Leech, Geoffrey. 1993. Principles of Pragmatics. London: Longman.

Tim Penyusun. 2014. Kamus Besar Bahasa Indonesia. Jakarta: Gramedia

Murdiyatmoko, Janu. 2004. Sosiologi. Jakarta: Grafindo, 2004

Mahsun. 2014. Metode Penelitian Bahasa. Jakarta: Raja Grafindo

Sudaryanto. 1984. Metode Linguistik Bagian Kedua: Metode an Aneka Teknik Pengumpulan Data. Gadjah Mada University Press.

Stoel, Rubel. 2005. Focus in Manado Malay. Grammar Particle and Intonation. Leiden: CNWS Publication 